Građevinski materijali i konstrukcije

Building Materials and Structures

journal homepage: www.dimk.rs

doi: 10.5937/GRMK2103207M UDK: 624.9.042.7(496.5)

Technical paper 550.34(496.5)"2019"

\title{
Performance of RC frames in 26.11.2019. Albania earthquake: effects of irregularities and detailing ${ }^{*}$
}

\author{
Ivan Milićević( ${ }^{(1)}$, Marko Marinković ${ }^{1)}$, Nikola Blagojević(2), Svetlana Nikolić-Brzev ${ }^{3)}$ \\ 1) University of Belgrade, Faculty of Civil Engineering, Bulevar kralja Aleksandra 73, 11000 Belgrade, Serbia \\ 2) ETH Zurich, Department of Civil, Environmental and Geomatic Engineering, 8093 Zurich, Switzerland \\ 3) University of British Columbia, Department of Civil Engineering, Vancouver, Canada
}

\section{Article history}

Received: 31 July 2021

Received in revised form: /

Accepted: 30 August 2021

Available online: 30 September 2021

Keywords

$\mathrm{RC}$ frames,

irregularities,

reinforcement detailing,

ductility,

Albania earthquake

\begin{abstract}
The collapse and damage of large number of buildings during the November 26 , 2019 (Mw 6,4) Albania earthquake caused 51 fatalities and injuries to at least 910 people. Most of collapsed or heavily damaged buildings were RC frame buildings. Although RC frame system is considered as very ductile seismic force-resisting system, its behaviour during earthquake highly depends on: (1) regularity in plan and elevation, and (2) global and local ductility. Based on the authors' visit to the earthquake-affected area on behalf of the Serbian Association of Earthquake Engineering and observations of collapsed and damaged buildings, it was concluded that among main reasons for underperformance of these flexible systems were inadequate analysis of interaction between infill walls and RC frames and reinforcement detailing of $\mathrm{RC}$ members.
\end{abstract}

\section{Introduction}

Located in a seismically active area, the territory of Albania has been exposed to 7 earthquakes of magnitude greater than 6.0 in the last 100 years. Only two months after two earthquakes of magnitude $M_{w}$ larger than 5.0 that occurred in September $2019\left(M_{w}=5.6\right.$ and $\left.M_{w}=5.1\right)$, at 3:45 a.m. on November 26, 2019 the western part of central Albania was hit by an earthquake of magnitude $M_{w} 6.4$ [1]. This was the strongest earthquake to hit Albania in the last 40 years. The epicentre of the earthquake, with a focal depth of $22 \mathrm{~km}$, was $15 \mathrm{~km}$ from Mamurras, $22 \mathrm{~km}$ from the city of Durrës and $30 \mathrm{~km}$ from the capital Tirana (Fig. 1(a)). The main shock was followed by about 20 aftershocks of magnitude greater than 4.0.

As a result of the collapse and damage of a large number of buildings, 51 people were killed and over 910 were injured, while more than 200,000 people were affected by the earthquake [2]. In total, about 95,000 housing units (18\% of the total number in the affected municipalities), 321 educational institutions (24\%) and 36 health institutions were damaged, with total losses of 985 million euros. Majority of collapsed and significantly damaged buildings were located in the city of Durrës, which were predominantly constructed of reinforced concrete, and in the town of Thumanë, which were predominantly masonry buildings with prefabricated hollow reinforced concrete floor and roof systems.

The Serbian Association for Earthquake Engineering (SUZI-SAEE) formed a four-member team that visited the areas affected by the earthquake a month after the earthquake. The SUZI-SAEE team, which consisted of the authors of this paper, visited several villages and towns, including Tirana, Durrës, Krujë, Fushë-Krujë, Thumanë and Bubq.

After the survey of the damaged buildings, it was concluded that most buildings that experienced collapse or significant damage were constructed using the system of monolithic reinforced concrete (RC) frames, which had several structural deficiencies. Note that many RC frame buildings in Durres which suffered severe damage during the November 26, 2019 earthquake, were not damaged in the lower intensity earthquakes that occurred only two months earlier [6]. The main reason for severe damage of these RC frame buildings in the November 2019 earthquake was spectral accelerations which were higher than expected for flexible structures. The earthquake also revealed detailing deficiencies and effect of structural irregularities which negatively affected the seismic performance of these buildings. Fig. 1(b) shows that the spectral accelerations of November 26 earthquake were approximately equal to the elastic spectral accelerations according to the KTP-N.2-89 code. It can be seen from the chart that the predominant period corresponding to the peak spectral acceleration was in the range of $1.0 \mathrm{sec}$, with the peak ground acceleration (PGA) of $0.196 \mathrm{~g}$ and the maximum spectral acceleration of more than $0.5 \mathrm{~g}$. It should be noted that the response spectrum for the Durrës station shown in Fig 1(b) was derived using the ground acceleration records corresponding to the initial 15 seconds of the main shock (the recording was discontinued due to a power outage in the station caused by the earthquake) [3].

\footnotetext{
* Paper presented at ASES 2020 Symposium, Arandjelovac, Serbia, May 2021.

Corresponding author:

E-mail address: ivanm@imk.grf.bg.ac.rs
} 


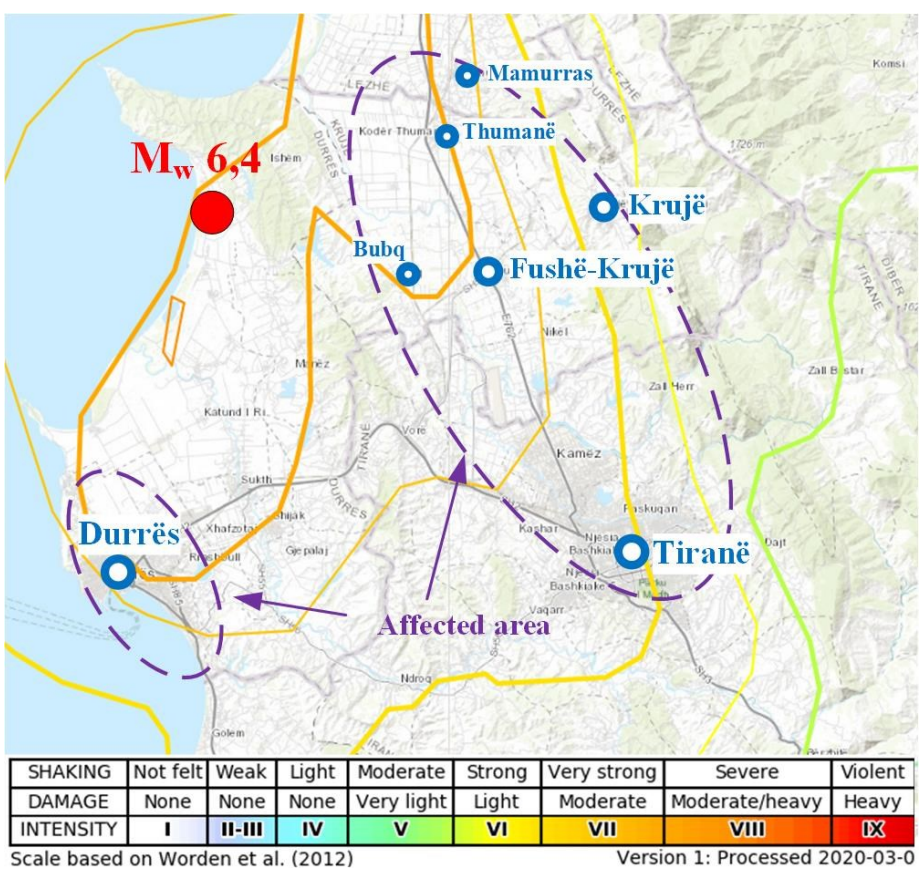

a)
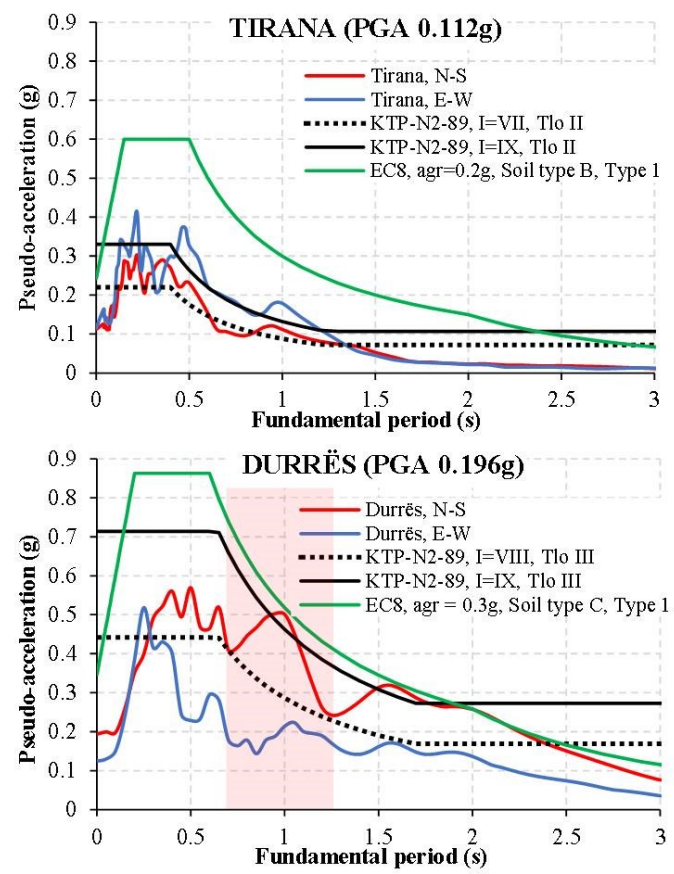

b)

Figure 1. Earthquake in Albania 26.11.2019: a) Map of the affected area [1], b) Comparison of the earthquake spectrum with elastic spectra, according to [3], [4] and [5]

This paper presents observations and conclusions of the SUZI reconnaissance team pertaining the causes of collapse and damage of buildings with RC frame structures in the November 26, 2019 Albania earthquake. Since over 30 damaged buildings were completely demolished and the ruins were cleared before the arrival of the SUZI team in Albania, the conclusions were made based on a visual inspection of the remaining damaged buildings and information gathered in the field, various reports and analysis of seismic regulations and construction practices in Albania. The aim of this paper is to highlight negative consequences of inadequate reinforcement details for local ductility of RC elements, as well as inadequate treatment of irregularities in flexible RC frame systems. These irregularities were caused by inadequate building configuration and unfavourable influence of elements which are usually disregarded in seismic design, e.g., masonry infill walls, stairs, etc.

\section{Construction practice and regulations in Albania: reinforced concrete frames}

Before 1990s, unreinforced masonry buildings and prefabricated large panel RC buildings prevailed in Albanian construction practice. At the beginning of the 1990s, the construction of buildings with monolithic RC frame structures became prevalent. This structural system became dominant in construction practice after the adoption of the Albanian seismic code KTP-N.2-89 [5]. In most cases, RC frame buildings had one-way or two-way ribbed RC slabs with polystyrene or clay masonry infills, as shown in Figs. 2(a) and 2(b), respectively. In this floor system wide/shallow beams span between interior columns while in some cases deeper beams may be provided at the perimeter. The depth of these shallow beams is equal to the total floor thickness (on the order of $300 \mathrm{~mm}$ ), which matches the minimum required

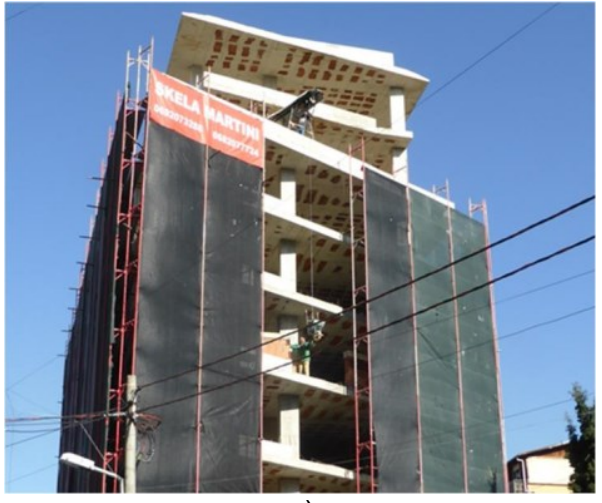

a)

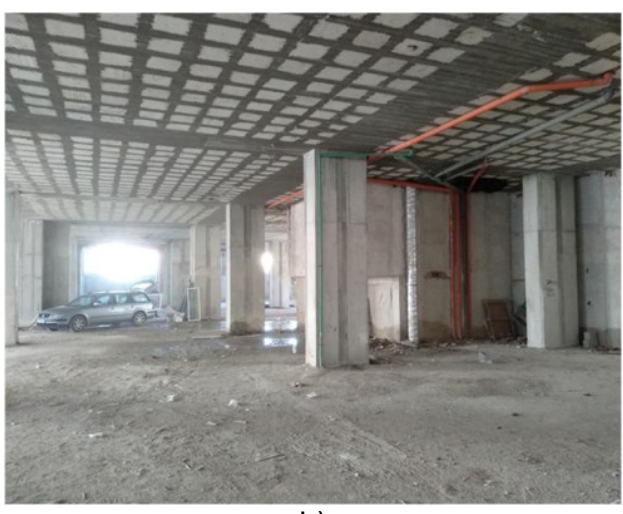

b)

Figure 2. Typical examples of RC frame buildings in Albania:

a) a building during construction, b) interior of an existing building 
depth of RC beams prescribed by the KTP-N.2-89 code [5], while the beam width is greater than or equal to the corresponding column dimension. In Albanian engineering practice, these shallow beams are often designed in the same manner as deeper RC beams. These buildings are usually designed and constructed either without any RC structural walls or with a relatively few walls, even in case of taller multi-storey buildings which are more than 10-storey high. As a result, the seismic force resisting system of these buildings consists of rather flexible RC moment-resisting frames (also known as bare frames).

Masonry infills, used as partition and façade walls, are in the form of multi-perforated clay blocks with horizontally aligned holes which is not common in practice other countries (e.g. in Serbia). Layout of the masonry infills in elevation and plan of the building depends on its function and position in relation to other buildings. There were many cases of buildings with open ground and first floors, with infills existing only at the higher floors. In other cases, masonry infills are unevenly distributed in plan (usually in buildings located at corners of a building block).

This structural system is addressed by the seismic code KTP-N.2-89 [5], which was published in 1989. According to KTP-N.2-89, seismic analysis and design of a structure is based on the reduced seismic load compared to a system with linear elastic behaviour. The values of the reduction factor depend on the type of the structural system and its presumed ductility. For RC frames with masonry infills which do not participate in resisting of seismic forces, the value of the reduction factor is between 2.63 and 4.0 (depending on the flexibility of RC columns). It should be noted that this is usual approach, although it is well-known that infill walls participate in resisting seismic forces, thus bring additional stress to the surrounding frame. The presumed ductility of the system is ensured by meeting the relatively strict detailing requirements for reinforcement in RC columns and beams, e.g. reduced spacing of stirrups/ties in critical areas and at splices of longitudinal reinforcement, minimum diameters of stirrups, maximum distances between restrained and unrestrained longitudinal bars in columns, lap splice lengths, etc. For buildings irregular plan or elevation, the code requires the application of a more accurate calculation method, which takes into account the contribution of higher vibration modes through multi-modal analysis (without increasing the seismic load). The displacement control is ensured through limiting inelastic displacements (the principle of "equal displacements"); however, the code does not explicitly prescribe displacement limits.

It is important to emphasize that, according to local experts, the code KTP-N.2-89 [5] was seldom applied in Albanian engineering practice in the period 1990-2000 (although its application was mandatory). The extent of KTPN.2-89 code in the period 2001-2012 is also unknown. In addition to KTP-N.2-89, seismic design codes from other countries such as American design codes (since 1995) and Eurocodes (since 2005) have been applied on a voluntary basis on some projects.

\section{Types and causes of damage of buildings with RC frame system}

High spectral accelerations, combined with characteristic structural deficiencies, led to the collapse and damage of large number of buildings with RC frame structures in the November 26, 2019 earthquake. The inspection of damaged buildings revealed that each building had two or more deficiencies, such as:
- Irregularity in plan and/or elevation of flexible seismicforce-resisting system, most often due to the influence of masonry infills or staircases,

- Inadequate reinforcement detailing for local ductility of $\mathrm{RC}$ frame elements,

- Interaction of RC frames and masonry infills,

- Insufficient width of seismic gaps, which caused pounding of the adjacent buildings.

\subsection{The effect of irregularities in RC frame structures}

In most cases, structural irregularities of buildings located in the area affected by the November 26 earthquake were caused by the interaction of highly flexible RC frame structures with masonry infills or stair cases. In engineering practice, stiffness of these elements is often neglected in design of RC buildings. The most common types of irregularities were "soft storey", "short"/"captive" column effects, and asymmetrical stiffness distribution in plan which caused torsional effects during the earthquake.

Examples of collapsed buildings in Albania due to the November 26 earthquake are shown in Fig. 3. The "soft storey" collapse was caused by a large difference in the lateral stiffness between adjacent floors-usually ground floors that were more flexible than upper floors. This behaviour is typical for flexible RC frame systems, which are common in Albania. Vertical irregularities were caused by unevenly distributed masonry infills in buildings, with open spaces at the ground floor level (garages, office space, shops, restaurants, etc.), while at the other floors there was a masonry infill (usually housing units). Due to presence of masonry infills and the resulting increased stiffness at higher floor levels, deformation demands on RC columns at open lower floors were significantly increased, which most likely resulted in structural damage and collapse. It should also be noted that Hotel Ljubljana (see Figure 3(d)) had three added floors (vertical extension). The other cause for significant damage of RC columns is their smaller dimensions compared to dimensions of RC beams, as shown in Fig. 6(a).

The "short-column" effect most often occurs when some parts of staircase (usually on intermediate landing) are supported by the RC columns or a partial masonry infill is constructed up to a certain height of the RC column due to openings (e.g. windows), acting as a lateral restraint along the column height. Damaged RC columns caused by this effect are presented in Figs. 4(a) and 4(b), respectively. Due to the lateral restraint of RC column provided by the staircase or the partial masonry infill, the column height is smaller. Shortening of RC column leads to increased localized stiffness and internal forces in the column itself (usually shear forces), for which RC column is usually not designed.

Fig. 5 shows significant earthquake damage and collapse of flexible structures due to torsional effects. The damage was caused by "secondary elements", specifically masonry infills and stairs, which are often neglected in seismic design practice. Fig. 5(a) illustrates the effect of shifting the position of the centre of stiffness of the structure due to the restrained $\mathrm{RC}$ columns at the stair support locations. Torsional effects caused an increase of forces in elements on the opposite side, and significant damage of the RC columns along the façade. The damage of an RC column which supports the staircase in this building is shown in Fig. 4(a). The building also had an open space at the ground floor. Fig. 5(b) shows the collapse of a corner building that had two adjacent open sides at the ground floor level with masonry infill walls along the other two sides. The ruins were cleared before the authors' reconnaissance, but it is believed that the collapse 


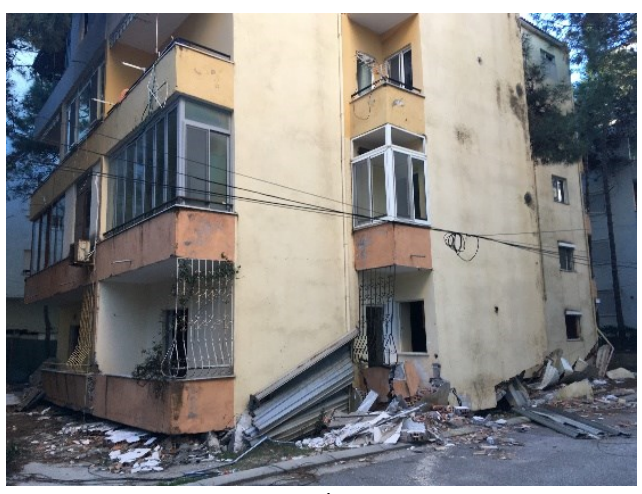

a)

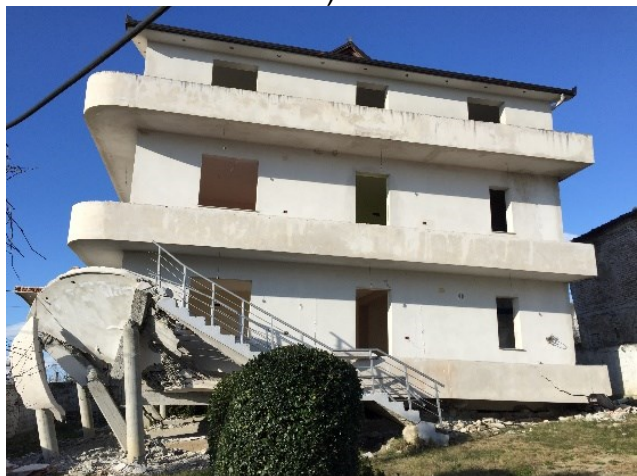

C)

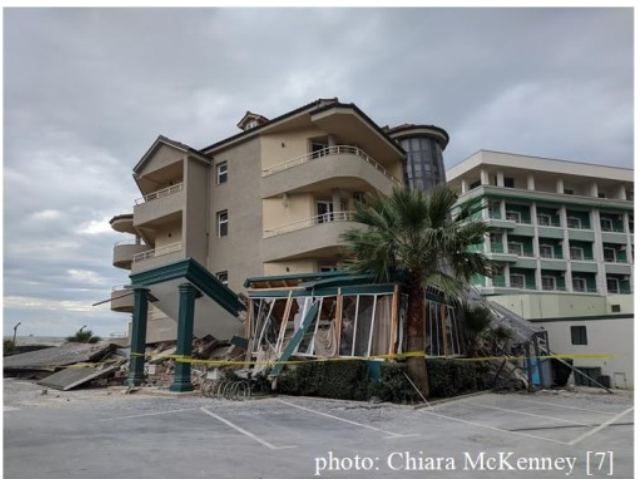

b)

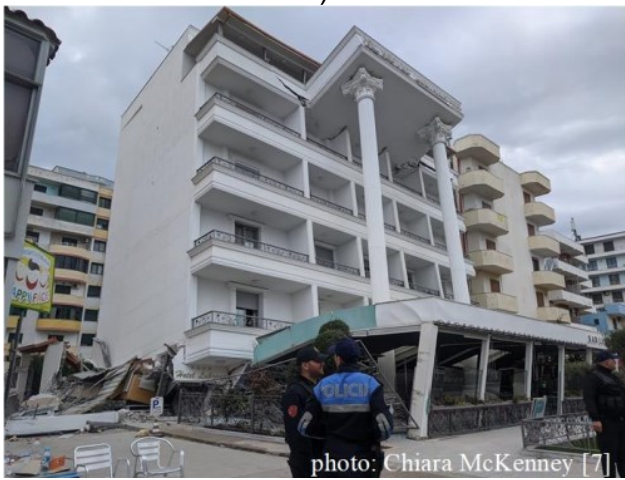

d)

Figure 3. Examples of building collapses due to "soft storey" effect in the November 26, 2019

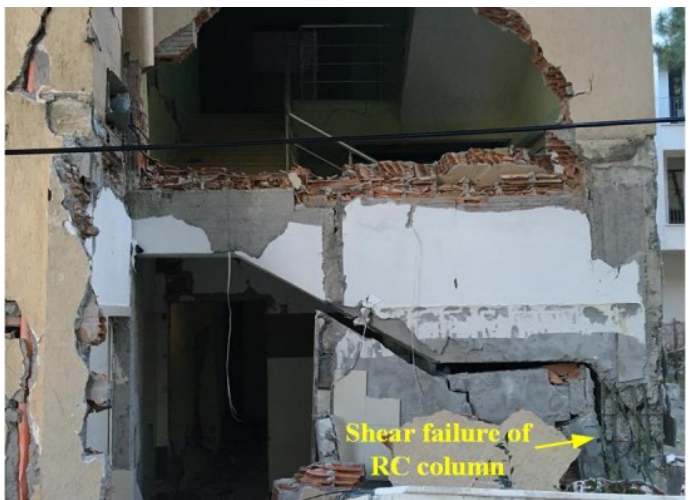

a)

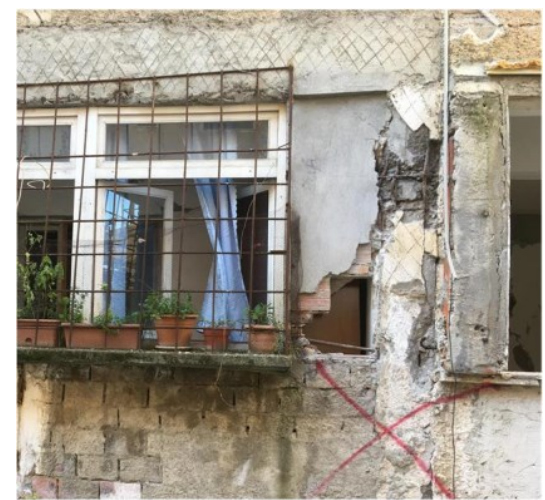

b)

Figure 4. Examples of RC column damage due to "short column" effect in the Albania earthquake caused by: a) intermediate staircase landing, b) partial masonry infill due to openings

was primarily due to inadequate detailing of $\mathrm{RC}$ members and torsional effects caused by a significant increase in stiffness on sides with masonry infill and an eccentricity of the centre of mass $(\mathrm{CM})$ relative to centre of stiffness $(\mathrm{CK})$.

\subsection{Inadequate reinforcement detailing of RC frame elements}

Apart from structural irregularities, several typical flaws in reinforcement detailing for the local ductility of the elements of RC frames (columns and beams), were observed in most of the damaged and collapsed buildings. Examples of these flaws are shown in Fig. 8. The authors believe that the most common detailing flaws were:
(1) A single perimeter tie in RC columns in "critical" regions (according to [5], for RC columns with cross section dimensions larger than $30 \mathrm{~cm}$, there should be at least 2 ties);

(2) Widely spaced stirrups/ties in "critical" regions and/or outside the "critical" regions of beams and columns (according to [5], for IX seismic zone spacing of ties in RC columns should be less than 8 diameters of longitudinal bars or $10 \mathrm{~cm}$ );

(3) Lack of or complete absence of stirrups in beamcolumn joint regions;

(4) Ties with $90^{\circ}$ hooks and insufficient anchorage length (according to [5], $135^{\circ}$ hooks with straight part not shorter than 10 tie diameters are mandatory);

(5) Ties with $6 \mathrm{~mm}$ diameter in RC columns (according to [5], for seismic zone IX diameter of ties should be at least $8 \mathrm{~mm}$ ): 
(6) Insufficient lap splice length when (often 100\% spliced reinforcement at one floor);

(7) Insufficient anchorage length of longitudinal beam reinforcement (without hooks).

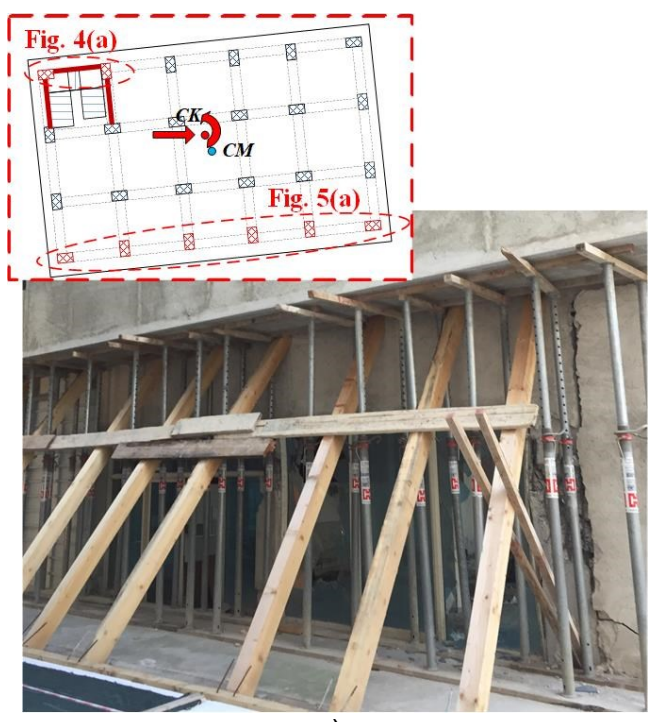

a)
A few examples of highlighted detailing flaws are shown in Fig. 6.

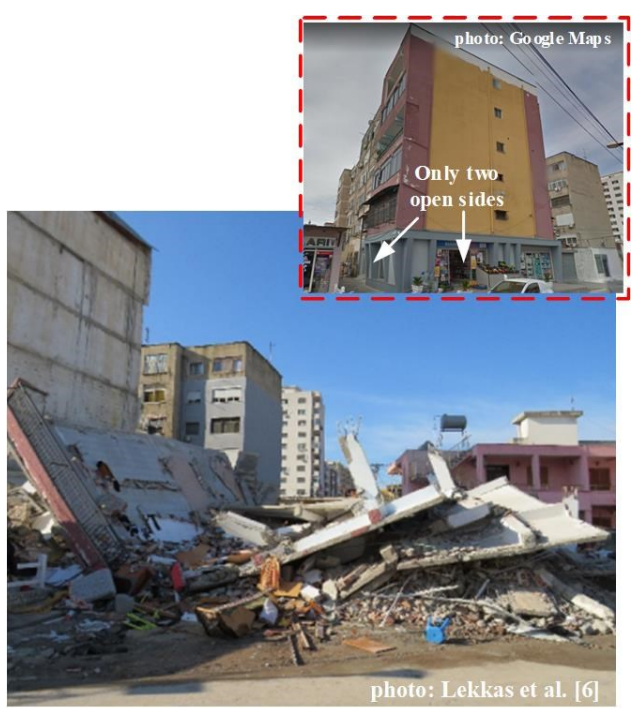

b)

Figure 5. Examples of damage and collapse of a building in Durres due to torsional effects: a) shifting of centre of stiffness due to the corner staircases, $b$ ) the influence of masonry infills

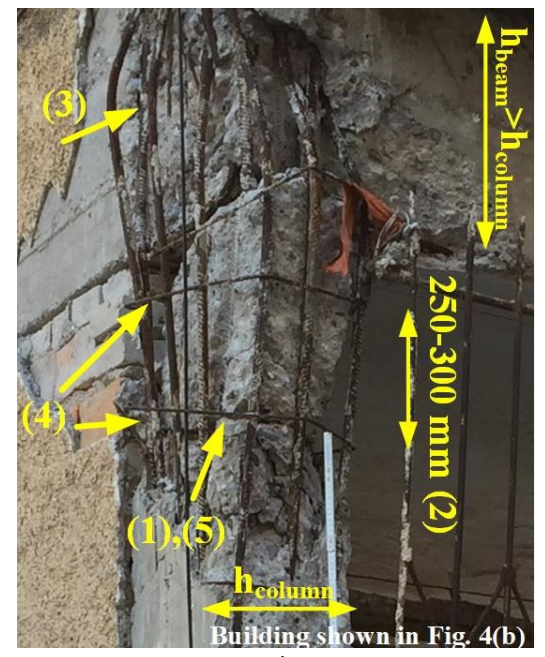

a)

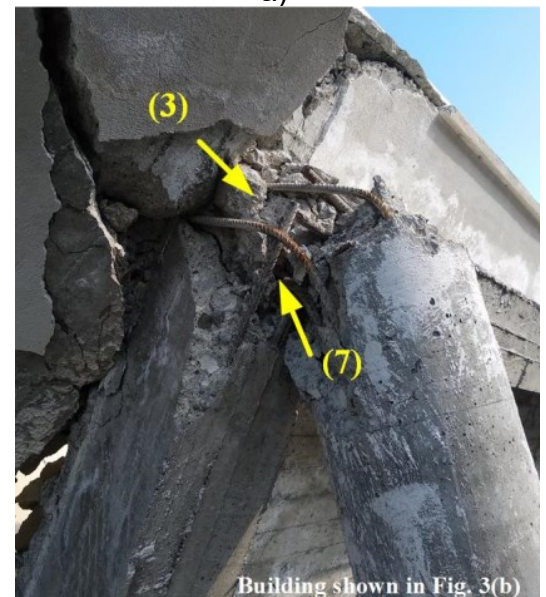

b)

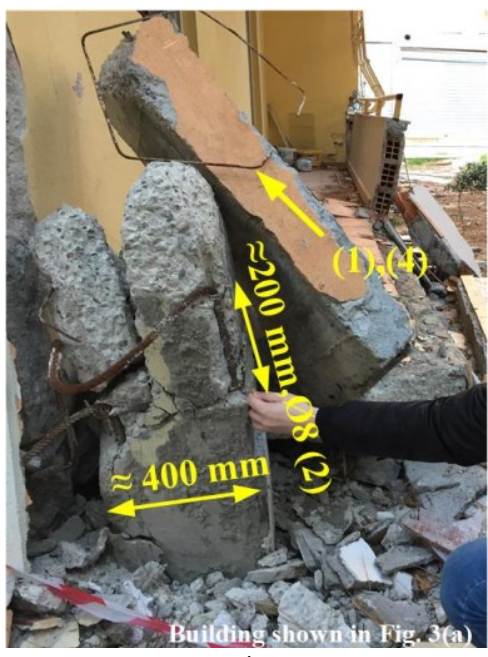

c)

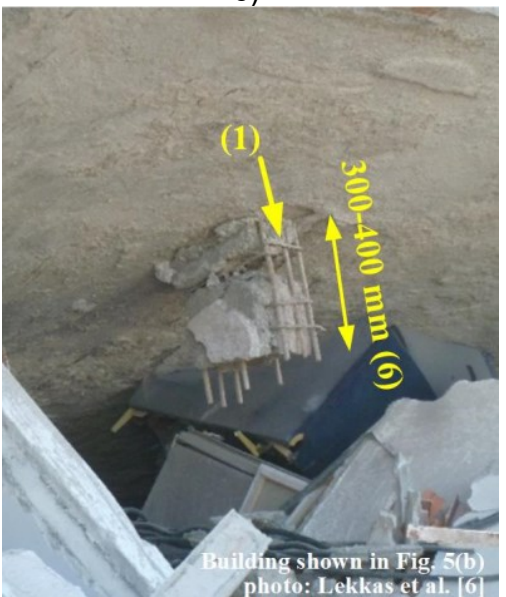

d)

Figure 6. Examples of inadequate detailing of reinforcement in $R C$ columns and beams 
3.3 Pounding of RC buildings and damage of RC columns due to interaction with infill walls

Several buildings suffered minor damage in the earthquake due to pounding, which was caused by insufficient width or absence of seismic gaps. An example of damage caused by this effect is shown in Fig. 7. In this case, the building experienced permanent inter-storey drifts. The interaction caused damage such as crushing of concrete cover (see Fig. 7(b)) and cracking of infill walls made out of concrete blocks as well as RC columns (see Fig. 7(c)) is the result of their interaction. This mechanism is explained in detail in [8].

\subsection{Behaviour of RC frame structures of newer buildings with damaged masonry infill walls}

Most of the buildings that sustained significant damage or collapse during the November 26 earthquake were built between 1990 and 2010. Although the buildings built after 2010 also sustained damage in the earthquake, the level and extent of damage to the structural elements of these buildings were relatively small. The masonry infills suffered most of the damage. Although these (mostly tall) buildings had flexible RC frame structures, the authors believe that RC elements with large dimensions had a significantly higher load-bearing capacity compared to the masonry infills. Therefore, due to large inter-storey drifts at lower floor levels (typical for frame structures), only masonry infills experienced significant damage (see Figs. 8(a) and 8(b)).
Minor damage of RC elements can be attributed to adequate detailing of reinforcement for local ductility (see Fig. 8(c)).

\section{Conclusions and recommendations for seismic design}

Many buildings in the western part of central Albania were damaged by the November 26, 2019 earthquake. Despite the existence of the Albanian seismic code which prescribes detailed provisions for design and detailing of reinforcement in $\mathrm{RC}$ frame elements, many buildings with this structural system experienced significant damage or collapse. Given the high demands in terms of spectral accelerations that were approximately equal to the design accelerations for flexible systems corresponding to fundamental periods of 0.8 to $1.2 \mathrm{~s}$, several key "weaknesses" of RC frame structures came to the fore. One of the main reasons for the damage was inadequate analysis of various irregularities caused by the unfavourable influence of "secondary elements" - masonry infills and staircases, which completely changed the assumed behaviour of flexible $\mathrm{RC}$ frames. The second reason was poor detailing of reinforcement in $\mathrm{RC}$ columns, beams and beam-column joints. As a result, the provided ductility of the structures was significantly less than expected. Since, in the Republic of Serbia, RC frame structures are quite common in residential and commercial buildings and the maximum ground acceleration in Durres was $0.196 \mathrm{~g}$ (according to Eurocode 8 , for the large part of Serbia peak ground acceleration is in

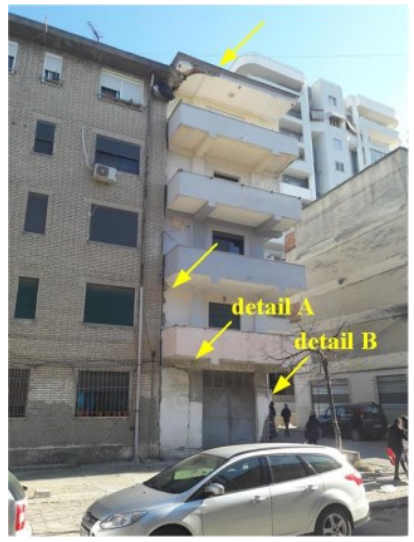

a)

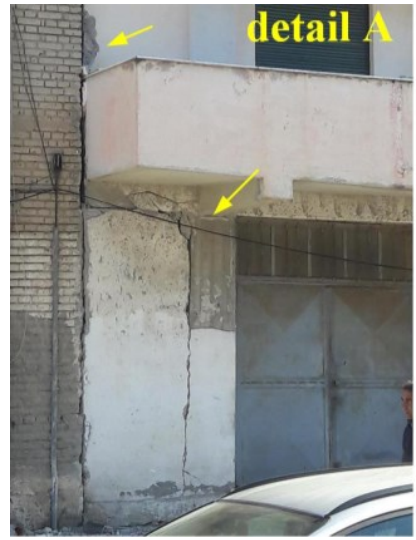

b)

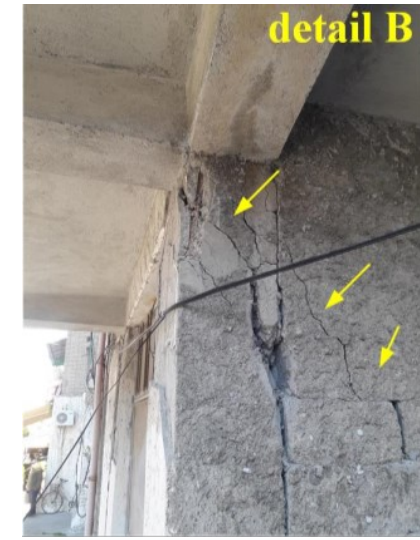

c)

Figure 7. Example of damage caused by pounding of adjacent buildings $(a, b)$ and interaction between $R C$ frames with infill walls (c)

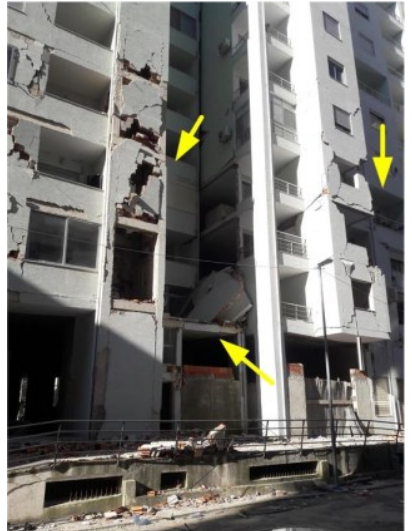

a)

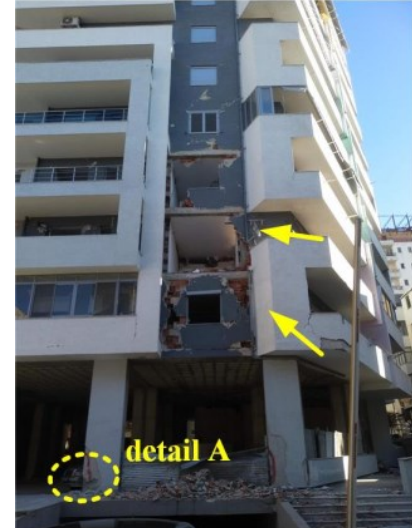

b)

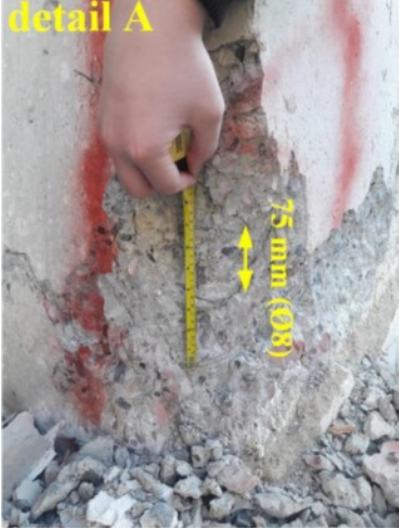

C)

Figure 8. Examples of damage to modern buildings with RC frame structure 
range $0.15 \mathrm{~g}-0.20 \mathrm{~g}$ ), experiences from this earthquake are relevant to Serbian engineering practice. In contemporary seismic design codes (such as Eurocode 8) detailed engineering analysis is required to ensure reliable behaviour of $\mathrm{RC}$ frame structures during earthquakes. Alternative solution is to provide sufficient amount of RC walls, which would reduce the flexibility of the entire structure and mitigate highlighted problems.

\section{Acknowledgement}

The authors would like to acknowledge the contribution of Markel Baballëku (Polytechnic University of Tirana-UPT), dr. Brisid Isufi (University NOVA, Lisbon, Portugal), prof. Merita Guri and prof. Ilda Rusi (POLIS University, Tirana) for sharing data and providing kind assistance before, during and after authors' reconnaissance to the affected areas of Albania after the November 26, 2019 earthquake.

\section{References}

[1] U.S. Geological Survey (USGS): M $6.4-15 \mathrm{~km}$ WSW of Mamurras, Albania, https://earthquake.usgs.gov/earthquakes/eventpage/u s70006d0m/executive, (22.4.2020.)
[2] UNDOP, WB \& EU: Post-Disaster Needs Assessment - Albania. United Nations Development Program, World Bank and European Union, 2020.

[3] Duni L., Theodoulidis N.: Short note on the November 26, 2019, Durres (Albania) M6.4 earthquake: strong ground motion with emphasis in Durres city, Institute of Engineering Seismology and Earthquake Engineering (ITSAK), 2019.

[4] Institute of GeoSciences, Energy, Water and Environment: StrongMotionRecords_Durresi earthquake_26November2019,https://geo.edu.al/new web/?fq=november\&gj=gi2,_(22.4.2020)

[5] KTP-N.2-89: Kusht teknik projektimi per ndertimet antisizmike, Akademia e Shkencave (Qendra Sizmologjike) \& Ministria E Ndertimit (Drejtoria e Projektimeve), 1989.

[6] Lekkas E., Mavroulis S., Papa D., Carydis P.: The November 26, 2019 Mw 6.4 Durrës (Albania) earthquake, Newsletter of Environmental, Disaster and Crisis Menagment Stategies, 2019.8

[7] McKenney C,: Reconnaissance Observation Report Albania M6.4 Earthquake on November 26, 2019, 2019.

[8] M.Marinković, S. Brzev, M. Baballëku, B. Isufi, N. Blagojević, I. Milićević, Ž. Žugić, P. Bursać, Out-ofplane behaviour of loadbearing and non-structural masonry walls during recent earthquakes, 1st Croatian Conference on Earthquake Engineering, Zagreb, Croatia, 22-24 March, 2021. 
